\title{
IMPROVED BASIC MOTION LEARNING THROUGH BALL MODIFICATION MEDIA AS A MEANS OF LEARNING TO PASS UNDER VOLLEYBALL
}

\author{
Made Linaldo ${ }^{1}$, Hartati $^{2}$, Syafaruddin ${ }^{3}$, Iyakrus $^{4}$ \\ Universitas Sriwijaya ${ }^{1,2,3,4}$ \\ madeyelvi@gmail.com
}

\begin{abstract}
The purpose of this study is to find out the improvement of basic motion learning through ball modification as a learning aid to pass under in students of grade V of State Elementary School 35 Talang Kelapa District. The research method is class action research (PTK) with kemmis and taggart model, namely through the stages of planning, action, observation and reflection. The object of the study was a student of class V of State Elementary School 35 Talang Kelapa Banyuasin Regency. Data collection using evaluation sheets of learning outcomes is affective, psychomotor and cognitive movement material basic Volleyball technique of passing under. Data analysis uses percentage analysis. The results showed that: a) There was an increase in the completion of the results of learning the basic motion of the ball game through the modification of the ball as a learning aid to learn lower passing in students of grade V of State Elementary School 35 District Talang Kelapa as many as 17 people or 57\% of the previous pre-cycle data which is as many as 9 people who completed learning or $30 \%$.b) There was an increase in the completion of the results of learning basic volleyball through ball modification as a tool to learn to pass under in students of class V Of Talang Kelapa District which is 17 people or $57 \%$ increased to 27 people or $90 \%$ of a total of 30 students. The study findings there was an increase in basic motion learning through ball modification as a learning aid to pass under in students of grade V of State Elementary School 35 Talang Kelapa Subdistrict. The implications of the results of the study can improve the results of learning the basic motion of the game of volleyball through the modification of the ball as a tool to learn to pass under.
\end{abstract}

Keywords: Ball Modification, Basic Motion, Volleyball

Accepted: 3th of September 2021

Correspondence author: Made Linaldo, Universitas Sriwijaya, Indonesia. E-Mail: madeyelvi@gmail.com DOI http://dx.doi.org/10.31851/hon.v5i1.6347 ${ }^{\text {do }}$

\section{(i) (2)}

Jurnal Halaman Olahraga Nusantara licensed under a Creative Commons Attribution-ShareAlike 4.0 $\underline{\text { International License }}$

\section{INTRODUCTION}

Volleyball learning has been known since elementary school, to advanced schools both first and intermediate level. Problems that are often faced by some elementary schools include State Elementary School 35 Talang Kelapa Subdistrict, 
are as follows: 1) Students are afraid to pass under, 2) Lack of motivation from teachers, and lack of interest in learning volleyball,3) Lack of facilities and infrastructure that support the learning process (Imawati et al., 2014). The emergence of these problems causes low student learning outcomes. A big ball game where one of them is the game of volleyball, although this game is very fun but different case for students who are new to the game of volleyball.

Learning volleyball although difficult to do, but this learning is very fun for students. In some learning situations for example students are very happy if the teacher orders students to learn to play volleyball (Gumilang \& Ramadan, 2019). Most students love this game, although some of them do not enjoy the game. With the activity of catapulting the ball into the air, cooperating between one student and another student makes this game has its own attraction for students (Arisman \& Agun Guntara, 2021). Passing is the ability to play the ball by passing through both arms or hands to friends or passed directly to the opponent's spaciousness (Iyakrus, 2012). Problems in learning basic movements passing below that appeared above turned out to have a great impact on the completion of student learning in elementary school. Of course, student learning problems must be overcome by teachers in order to be able to answer the results of learning to pass under in a perfect ball game (Okilanda et al., 2021). To overcome the problem of students in passing during ball learning, of course, the right learning model is needed (Putra et al., 2020).

According to (Effendy et al., 2020) states that a plan or pattern is used as a guideline in planning classroom learning or tutorial learning. This opinion researchers mean that in planning good learning guidelines must certainly adjust to the problems that arise in the school. While the above has been explained that the problem that arises in the situation of learning to teach volleyball games elementary school students is the occurrence of fear when students in passing under (Cahyanto \& Hidayat, 2015). The learning model that is considered appropriate in solving this 
case is how teachers modify learning aids to overcome students' fears in passing under on the ball game.

One of the modifications of learning aids that are expected to be able to overcome the fear of students in passing under on students of grade $\mathrm{V}$ of State Elementary School 35 Talang Kelapa Subdistrict is to modify rubber balls that can be used as a learning medium. Rubber balls can be used to overcome the weakness of students who are afraid when receiving the ball when about to make a passing. Rubber balls that have a softer surface when coming into contact with the student ball no longer experience pain when receiving the ball. The more often this is done by students, it is expected that students will be more accustomed and more able to pass under so that it has an impact on the perfection of student learning outcomes (Hasnah et al., 2018).

\section{METHOD}

This study was conducted on July 12 to 31, 2021 at SD Negeri 35 Talang Kelapa. Coconut gutters. The object of the study was a class V student of 30 students. The method in this study is a class action research (PTK) with Kemmis and Taggart models that are through the stages of planning, action, observation and reflection. The object of the study was a student of class V of State Elementary School 35 Talang Kelapa Banyuasin Regency. Data collection using study outcome evaluation sheets i.e. the ability of psychomotor, and cognitive affections. Data analysis uses percentage analysis.

\section{RESULTS AND DISCUSSIONS}

\section{Description of Initial Data (Pre-Cycle)}

Based on preliminary data, the results of learning the basic movement of ball volleyball passing technique under the students of State Elementary School class 35 Talang Kelapa District Banyuasin,

Table 1. Completion of Pre-Cycle Learning Outcomes

Criterion

\section{Frequency}

$\mathrm{Fr} \quad \mathrm{Fa}$

\section{3 | Halaman Olahraga Nusantara \\ copyright@Made Linaldo}




$\begin{array}{ccc}\text { Not Complete } & 21 & 70 \% \\ \text { Done } & 9 & 30 \%\end{array}$

Based on the table above, students who experience the completion of learning outcomes. The basic movement of the ball game in the lower passing technique is 9 people or by $30 \%$, while the unfinished as many as 21 people or $70 \%$, thus learning the basic motion of the ball through the modification of the ball as a learning aid of lower passing is needed to improve student learning outcomes.

\section{Cycle I Learning}

planning

Planning for learning, some of which must be prepared by researchers include preparing a learning plan with passing material under the Volleyball, compiling a learning observation sheet (Hartati et al., 2017). Develop student assessment instruments, prepare learning resources needed in learning, Prepare learning facilities and media

What is needed in learning.

Action

Taking action, researchers take learning steps starting from the introduction, core and closing. For the core activities the details are As follows:

1) Pre-prepared media is presented to students through learning methods.

2) Teachers begin the practice of learning basic movements of lower passing in the game of Volleyball through rubber ball aids. The basic movement core activity steps are as follows:

a. Students are taught to set the pace in performing the underward passing.

b. Students are taught to regulate hand movements through arm swings in performing underward passing.

c. Students are taught the perfect combination of locomotor and non-locomotor movements towards the attitude of lower passing through the game by using a modified yng ball i.e. a rubber ball.

Observation 
Observation is an observation made by researchers in seeing and analyzing the teaching and learning process using established methods. Observations include:

1. Evaluate the learning process onaffective, Kognitive and Sikomotoric Paspects.

The evaluation data of the results of learning the basic motion of the ball game in the lower passing technique is as follows:

Table 2. Completion of Cycle I Learning Outcomes

\begin{tabular}{ccc}
\hline \multirow{2}{*}{ Criterion } & \multicolumn{2}{c}{ Frequency } \\
& Fr & Fa \\
\hline Not Complete & 13 & 43,33 \\
Done & 17 & 56,67 \\
\hline
\end{tabular}

Based on the table above, it can be explained that students who experience the completion of the results of learning the basic motion of the game of volleyball in the lower passing technique is 17 people or $57 \%$, while the unfinished as many as 13 people or $43 \%$.

2. Observing learning activities, which based on the observations of researchers during the teaching and learning process, obtained information that the process of learning activities to teach basic motion ball games through ball modification as a means of learning to pass under in students of grade V of State Elementary School 35 Talang Kelapa went well because the percentage of KBM observation reached $80 \%$.

Reflexology

In cycle I learning, the achievement of learning outcomes improved from pre-cycle data, where previously pre-cycle data that experienced learning completion was only 9 people or $30 \%$ increased to 17 people or $57 \%$ of the total 30 students.

The process of learning to teach the basic movement of the game of volleyball through ball modification as a means of learning to pass under its essence has advantages and disadvantages (Rihatno, \& Gunawan, 2018).

1. Advantages of Learning

\section{5 | Halaman Olahraga Nusantara copyright@Made Linaldo}


a) In the aspect of learning planning is neatly organized and good, starting from the preparation of RPP, Syllabus and evaluation sheet.

b) Teachers are able to translate students' learning desires through the help of modified balls.

c) Teachers make learning the basic motion of the Volleyball on the lower passing becomes less feared by students because the emphasis of the ball that modification becomes softer.

2. Lack of learning

a) Students still haven't maxed out adaptation with modified balls

b) Students have learning motivation, but not enough time to translate the teacher's wishes.

c) Mastery of the class is still a problem that must be thought of in the next cycle.

\section{CycleLearning I}

planning

Planning for learning, some of which must be prepared by researchers include, preparing a learning plan with passing material under volleyball, arrange learning observation sheet,arrange assessment instrument of students, preparing learning resources needed in learning, preparing learning facilities and media needed in learning (Riantoso et al., 2010).

Action

Taking action, the researcher takes learning steps such as introduction, core and closing. For the core activity steps are as follows:

1) Pre-prepared media is presented to students through learning methods.

2) Teachers begin the practice of learning basic movements of lower passing in the game of Volleyball through rubber ball aids. The basic movement core activity steps are as follows:

a. Students are taught to set the pace in performing the underward passing.

b. Students are taught to regulate hand movements through arm swings in performing underward passing. 
c. Students are taught the perfect combination of locomotor and non-locomotor movements towards the attitude of lower passing through the game using a modified ball i.e. a rubber ball.

Observation

Observation is an observation made by researchers in looking at and analyzing the teaching and learning process using the same methods.

it's been set. Observations include:

1. Evaluating the learning process on affective aspects, cognitive $\mathrm{K}$ and physcomotor, then the table above can be spelled out in the distribution of completions below:

Table 3. Completion of Cycle II Learning Outcomes

\begin{tabular}{ccc}
\hline \multirow{2}{*}{ Criterion } & \multicolumn{2}{c}{ Frequency } \\
& $\mathrm{Fr}$ & $\mathrm{Fa}$ \\
\hline Not Complete & 3 & 10 \\
Done & 27 & 90 \\
\hline
\end{tabular}

Based on the table above, it can be explained that students who experience the completion of the results of learning the basic motion of the game of volleyball in the lower passing technique is 27 people or $90 \%$, while the unfinished as many as 3 people or $10 \%$.

2. Observing learning activities, which based on the observations of researchers during the teaching and learning process, obtained information that the process of learning activities to teach basic motion ball games through ball modification as a means of learning to pass under in students of grade V of State Elementary School 35 Talang Kelapa went well because the percentage of KBM observation reached $90 \%$.

Reflexology

Cycle II learning, the achievement of the completion of learning outcomes increased from cycle I data, where previously cycle I data that experienced the completion of learning 17 people or $57 \%$ increased to 27 people or $90 \%$ of the total 30 students. The process of learning to teach the basic movement of the game of 
$\overline{\text { volleyball through ball modification as a means of learning to pass under its essence }}$ has advantages and disadvantages.

1. Advantages of Learning

a) In the aspect of learning planning is neatly organized and good, starting from the preparation of RPP, Syllabus and evaluation sheet.

b) Teachers are able to translate students' learning desires through the help of modified balls.

c) Teachers make learning the basic motion of the Volleyball on the lower passing becomes not feared by siswa because the emphasis of the modified ball becomes softer.

d) Class mastery is particularly noticeable in this cycle, given that the errors in the first cycle are well studied.

2. Lack of learning

In the second cycle there are no weaknesses and shortcomings in teaching and learning activities, remembering all the shortcomings in the first cycle has been used as a basis for carrying out teaching and learning activities in the second cycle.

\section{Analysis of Improved Learning Outcomes}

Based on the analysis of improvement in learning outcomes, it can be seen that the percentage increase in learning outcomes from pre-cycle to the second cycle:

Table 4. Deviation increases student learning outcomes

\begin{tabular}{lcc}
\hline \multirow{2}{*}{ Cycle } & \multicolumn{2}{c}{ Completion } \\
& Frequency & Percentage \\
\hline Pre-Cycle & 9 & 30 \\
Cycle I & 17 & 57 \\
Cycle II & 27 & 90 \\
Deviation & 18 & $60 \%$ \\
\hline
\end{tabular}

Data obtained from the results of basic motion learning volleyball through ball modification as a learning aid to pass under in students of grade V Elementary 
School 35 Talang Kelapa,where in the pre-cycle frequencyof completion of students only 9 people who reached KKM or by $30 \%$ increased in the second cycle with a frequency of 27 people or by 90 . Thus the increase in the frequency of increase from pre-cycle to cycle two is as much as 18 people or by $60 \%$.

\section{DISCUSSION}

\section{Learning activities to teach cycle I}

Basic motion teaching and learning activities through ball modification as a learning aid to learn to pass under in students of class V of State Elementary School 35 Talang Kelapa District in cycle I stated that a) There was an increase in the completion of the results of learning basic motion ball game through ball modification as a tool to learn lower passing in students of class V Of State Elementary School 35 Talang Kelapa Subdistrict as many as 17 people from the previous pre-cycle data of as many as 9 people who completed learning. The process of learning activities to teach the basic movement of the game of volleyball through ball modification as a tool to learn to pass under in students of class $\mathrm{V}$ Elementary School Negeri 35 Talang Kelapa goes well.

Learning in cycle 1 has basically been carried out in accordance with the planned learning flow (Arisman \& Noviarini, 2021). Where starting from planning and actions directed to be able to complete student learning outcomes, but some obstacles occur in the first cycle, so that the level of achievement of learning success through observation sheets falls into the category of good but the completion of learning has not reached the desired number so it must be continued in cycle II learning.

The process of learning to teach the basic movement of the game of volleyball through ball modification as a means of learning to pass under its essence has advantages and disadvantages. The advantages of learning in the first cycle are:

1. In the aspect of learning planning is neatly organized and good, starting from the preparation of RPP, Syllabus and evaluation sheet. 
2. Teachers are able to translate students' learning desires through the help of modified balls.

3. Teachers make learning the basic motion of the Volleyball on the lower passing becomes less feared by students because the emphasis of the ball that domodification becomes softer.

While some of the shortcomings depicted in teaching and learning activities in the first cycle are as follows:

1. Students still have not maximally done adaptation with modified balls.

2. Students have learning motivation, but not enough time to translate the teacher's wishes.

3. Mastery of the class is still a problem that must be thought of in the next cycle. The advantages of learning in the first cycle should be used as a reference in the teaching and learning process in the second cycle. The thing that becomes the basis in the first cycle of learning is to use ball modification as a tool, making students' movements inpassing less feared, students increasingly interested in making movements (Arisman et al., 2021).

\section{Learning activities to teach cycle II}

In the activity of learning to teach basic motion through ball modification as a tool to learn to pass under in class V of State Elementary School 35 Talang Kelapa District in cycle II obtained the following results: a) There was an increase in the completion of the results of learning basic motion ball game through ball modification as a tool to learn lower passing in students grade V State Elementary School 35 District Talang Kelapa which is 17 people increased to 27 people out of a total of 30 students.b) The process of learning to teach basic motion ball game through ball modification as a tool to learn lower passing in class V students of State Elementary School 35 Talang Kelapa went well.

Based on the experience of the first cycle, researchers plan more serious learning in cycle II, where learning in the first cycle all aspects of errors are corrected, resulting in an increase in the results of learning the basic motion 
excellent. The weakness of learning in the first cycle has been overcome in the second cycle. In the second cycle students experience increased enthusiasm in learning, the ability to analyze more sharply, it is evidenced by the completion of learning outcomes. The process of learning to teach the basic movement of the game of volleyball through ball modification as a means of learning to pass under its essence has advantages and disadvantages. The advantages of learning in this second cycle are seen from

1. In the aspect of learning planning is neatly organized and good, starting from the preparation of RPP, Syllabus and evaluation sheet.

2. Teachers are able to translate students' learning desires through the help of modified balls.

3. Teachers make learning the basic motion of the Volleyball on the lower passing not feared by students because the emphasis of the modified ball becomes softer.

4. Class mastery is particularly noticeable in this cycle, given that the errors in the first cycle are well studied.

While learning deficiencies in the second cycle do not look weaknesses and deficiencies in teaching and learning activities, remembering all shortcomings in the first cycle has been used as a basis for carrying out teaching and learning activities in the second cycle.

(Effendy et al., 2020) One model that is able to overcome students' fears in making underward passing is to modify the ball into a rubber ball that can be used as a learning medium. Rubber balls can be used as a tool to overcome fear when receiving the ball when going to make a passing. Balls with a soft texture when coming into contact with the ball students no longer experience pain when receiving the ball. Researchers do the actual ball using a rubber ball (Okilanda et al., 2018). The more often this is done by students, it turns out that students will be more accustomed and more able to pass under so that it has an impact on the perfection of student learning outcomes. 
Some previous studies that are similar to researchers' research and support the results of research researchers are as follows conducted (Cahyanto \& Hidayat, 2015) by, where this study revealed the results of there is a significant influence on game modification on the results of learning passing over volleyball as evidenced by the results of the $t$ test, obtained the value of $t$ count $-2,749>t$ table -1.684 with signification level $0.05(5 \%)$. With the results of data analysis calculations can be known the large influence of game modifications on the learning outcome of passing over volleyball by $6.60 \%$. Another research is (Gumilang \& Ramadan, 2019) where this study explains the results that tool modifications can improve lower passing learning in students of class V of Pakapasan Hilir District Hantara Kuningan District, where in the first cycle there was an increase in learning outcomes by $73 \%$ and in the second cycle outcomes by $98 \%$.

\section{CONCLUSION}

Based on the findings of the results of research and data analysis, this study provides the conclusion that:

a. There was an increase in the completion of the results of learning basic motion of the game of volleyball through ball modification as a tool to learn to pass under in students of grade V of State Elementary School 35 Talang Kelapa District of 17 people or by $57 \%$ in cycle I learning.

b. There was an increase in the completion of the results of learning basic motion ball game through ball modification as a tool to learn to pass under in students of grade V of State Elementary School 35 Talang Kelapa District as many as 27 people or $90 \%$ in cycle II learning.

\section{REFERENCES}

Arisman, A., \& Agun Guntara, R. (2021). The Research Of Students' Motor Ability In Archery Extracurricular. Jurnal Maenpo: Jurnal Pendidikan Jasmani Kesehatan Dan Rekreasi, 11(1), 13. https://doi.org/10.35194/jm.v11i1.1216

Arisman, A., \& Noviarini, T. (2021). Tabata Workout dalam Meningkatkan 
Kebugaran Atlet Panahan. Halaman Olahraga Nusantara (Jurnal Ilmu Keolahragaan), 4(1), 12-22.

Arisman, A., Okilanda, A., Dwiansyah Putra, D., \& El Cintami Lanos, M. (2021). Resistensi Yoga dalam Meningkatkan Konsentrasi Ketepatan Memanah. Jurnal Patriot, 3, 71-81. https://doi.org/10.24036/patriot.v

Cahyanto, A. G., \& Hidayat, T. (2015). Effect of Game Modification On Learning Outcomes Passing Over Volleyball. Journal of Sports and Health Education. Vol 12 No. 3.

Effendy, F., Kharisma, Y., \& Ramadhan, R. (2020). Use of Volleyball Game Modifications To Improve Lower Passing Ability. Journal of Sports Education (JPO). IKIP PGRI Pontianak.

Gumilang, Y. T., \& Ramadan, G. (2019). Modification of Tools Against Lower Passing Ability in VolleyballGame. Journal of S.P.O.R.T (Sport, Sphysical, Education, Organization, Recreation, Training .

Hartati, Aryanti, S., \& Qodar, F. A. (2017). Development of Learning Athletic Learning Models Release Directly Based Games In Elementary School. International Seminar on Health, Physical Education, and Sport Science.

Hasnah, Suyuti, A., \& Hikmad, H. (2018). Efforts to Improve Upper Passing Learning Outcomes in Volleyball Games Through Modification of Learning Tools. Sportive Journal.

Imawati, Sada, C., \& Wakidi. (2014). Efforts to Improve Passing Skills in The Game of Volleyball by Playing Baring Sit. Journal of Physical Education, Health and Recreation.

Iyakrus, Anas. 2012. Improving Student Activeness In Learning Through a Play Approach. Proceedings international seminar UNNES.

Okilanda, A., Arisman, A., Lestari, H., Lanos, M. E. C., Fajar, M., Putri, S. A. R., \& Sugarwanto, S. (2018). Sosialisasi Petanque Sebagai Olahraga Masa Kini. Jurnal Bagimu Negeri, 2(1), 69-76. https://doi.org/10.26638/jbn.638.8651

Okilanda, A., Dlis, F., Humaid, H., Putra, D. D., Arisman, A., \& Muslimin, M. (2021). Defense Warm-Up Exercise Material for 13-Age Athlete Using Video Technology in Covid-19 Era. International Journal of Human Movement and Sports Sciences, 9(4), 629-634. https://doi.org/10.13189/saj.2021.090404 
Putra, D. D., Okilanda, A., Arisman, A., Lanos, M. E. C., Putri, S. A. R., Fajar, M., Lestari, H., \& Wanto, S. (2020). Kupas Tuntas Penelitian Pengembangan Model Borg \& Gall. Wahana Dedikasi : Jurnal PkM Ilmu Kependidikan, 3(1), 46. https://doi.org/10.31851/dedikasi.v3i1.5340

Riantoso, S., Simanjuntak, V. G., \& Yunitaningrum, W. (2010). Modification of Physical Education Learning Media in Junior High School Feeding Hedgehogs. Journal of Untan.

Rihatno, T., \& Gunawan. (2018). Improvement of Volleyball's Lower Passing Skills Through Modified Ball Learning Medium. Gladi Journal of Sports Science. 